УДК 655.3.022.1

๔ С. Ф. Морфлюк д.Т.н., професор, І. С. Карпенко, к.т.н., ст. викладач, НТУУ «КПІ», Київ, Україна

\title{
ЦИФРОВА СИСТЕМА \\ ІНТЕГРАЛЬНОГО КОНТРОЛЮ СУМІЩЕННЯ ФАРБ В АРКУШЕВИХ ДРУКАРСЬКИХ МАШИНАХ
}

\begin{abstract}
В статті запропоновано цифрову систему інтегрального контролю суміщення фарб для визначення локалізації порушення функціонування аркушевої друкарської машини, яка дозволяє зменшити технологічні втрати процесу друку та виконувати стабілізацію суміщення фарб з визначеною точністю у реальному масштабі часу.
\end{abstract}

Ключові слова: суміщення фарб; цифрова система інтегрального контролю; поздовжнє суміщення фарб; поперечне суміщення фарб; діагональне суміщення фарб; стабілізація суміщення фарб.

\section{Постановка проблеми}

Одним з головних параметрів якості друкарських відбитків, який необхідно контролювати під час друку в аркушевих друкарських машинах є параметр суміщення фарб. у сучасних друкарських машин механіка процесу друку має складний динамічний характер, що зумовлює вплив на якісне формування друкарських відбитків значної кількості факторів [1]. Проаналізувавши фактори, які мають найвагоміший вплив на суміщення фарб друкарської продукції, було виділено дві ї групи: перша - це порушення функціонування аркушепередавальної системи (нестабільність сил тертя, знос робочих механізмів, їх вібрації, зміщення зазорів у механізмах захватів, колове зміщення аркушепередавальних циліндрів у момент відкриття та закриття захватів та iн.), друга - порушення функціонування механізмів і пристроїв друкарської секції (значний тиск у зоні друкарського контакту, зміна положення друкарської форми, зміщення формного циліндра, порушення геометричних параметрів контактуючих циліндрів та ін.) [2]. Визначення причини значного зміщення орієнтації друкарських відбитків на аркуші відносно певної групи в реальному масштабі часу $є$ проблемним завданням.

Тому актуальним $€$ розроблення та дослідження цифрової системи інтегрального контролю суміщення фарб в аркушевих друкарських машинах для точного і достовірного визначення параметрів суміщення фарб, що забезпечує мінімізацію часу визначення причин порушення 


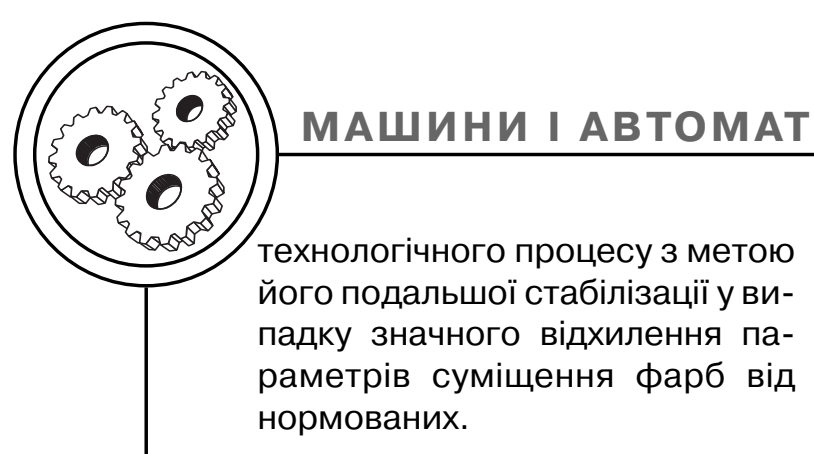

\section{Аналіз попередніх} досліджень

В аркушевих друкарських машинах з автоматизованими системами приведення фарб контроль суміщення друкарських відбитків здійснюється на основі сканування оптичною вимірювальною балкою, яка встановлюється на останній друкарській секції, спеціальних технологічних міток, що друкуються по обидві сторони аркуша [3, 4]. Виробники друкарського обладнання використовують мітки різноманітної форми (форми хреста, трикутника, трапеції та ін.), які дозволяють здійснювати контроль діагонального, поперечного та поздовжнього суміщення фарб. Мітки розділяються на опорні (мітки, що друкуються базовою фарбою на першій друкарській секції) та еталонні (мітки, що друкуються фарбами кожної друкарської секції починаючи з другої). Опорні мітки друкуються на першій друкарській секції рівномірно певну кількість разів, яка відповідає кількості секцій друкарської машини, а між ними друкуються еталонні мітки відповідної фарби. Параметри суміщення фарб визначаються відхиленням еталонних міток кожної фарби відносно опорних міток базової (як правило чорної) фарби.

Внаслідок використання в аркушевих друкарських машинах систем автоматичного виз- начення параметрів суміщення фарб, які виконують контроль після проходження папером останньої друкарської секції, при відхиленні параметрів суміщення фарб від нормованої величини (0,01 мм) збільшується кількість паперових втрат та час зупинки друкарської машини для визначення причини зміщення друкарських відбитків, що вимагає розроблення цифрової системи інтегрального контролю суміщення фарб (контроль суміщення фарб до входу аркуша в друкарську секцію та після друку відбитку), яка б дозволила мінімізувати технологічні втрати процесу друку та забезпечити визначену якість друкованої продукції.

\section{Мета роботи}

Метою статті $€$ розроблення цифрової системи інтегрального контролю суміщення фарб в аркушевих друкарських машинах для забезпечення точності та достовірності визначення параметрів суміщення фарб у друкарських машинах та їх подальшої стабілізації при мінімізації технологічних втрат процесу друку.

\section{Результати проведених досліджень}

Актуальним рішенням процесу об'єктивного контролю параметрів суміщення фарб та визначення причин їх відхилення від нормованої величини є застосування програмно-апаратного комплексу (ПАК) на основі засобів аналого-цифрового $\left(А Ц \Pi_{1,2,3,4}\right)$ та цифро-аналогового перетворення $\left(Ц А \Pi_{1,2}\right) \mathrm{iH}_{\text {- }}$ формації, оптичних датчиків 
сканування спеціальних міток у вигляді прямокутних трикутників, що друкуються по обидві сторони аркуша паперу та EOM 3 програмними засобами управління процесом контролю та стабілізації суміщення фарб в аркушевих друкарських машинах (рис. 1).

Функціонування цифрової системи інтегрального контролю суміщення фарб в аркушевих друкарських машинах складається з двох етапів (рис. 2).

Перший етап полягає у формуванні імпульсних сигналів 3 оптичних датчиків, які встановлюються у аркушепередавальній системі друкарської машини перед друкарськими секціями по обидві сторони проходження паперу й передають інформацію про його орієнтацію на основі спеціальних міток, що друкуються на першій друкарській секції. Імпульсні сигнали за допомогою аналого-цифрових перетворювачів (АЦП 1,2$)$ для лівої та правої міток перетворюються у масив цифрових кодів для подальшого запису, аналізу, обробки та визначення параметрів діагонального, поперечного, поздовжнього суміщення фарб $\left(\alpha, \mathrm{I}_{1}, \mathrm{I}_{2}\right)$ в EOM і напрямків їх стабілізації (diag, poper, pozd) [1].

На основі визначених характеристик суміщення фарб проводиться аналіз необхідності стабілізації процесу в друкарській секції за допомогою механізмів діагонального, осьового та колового приведення (умова проведення стабілізації:

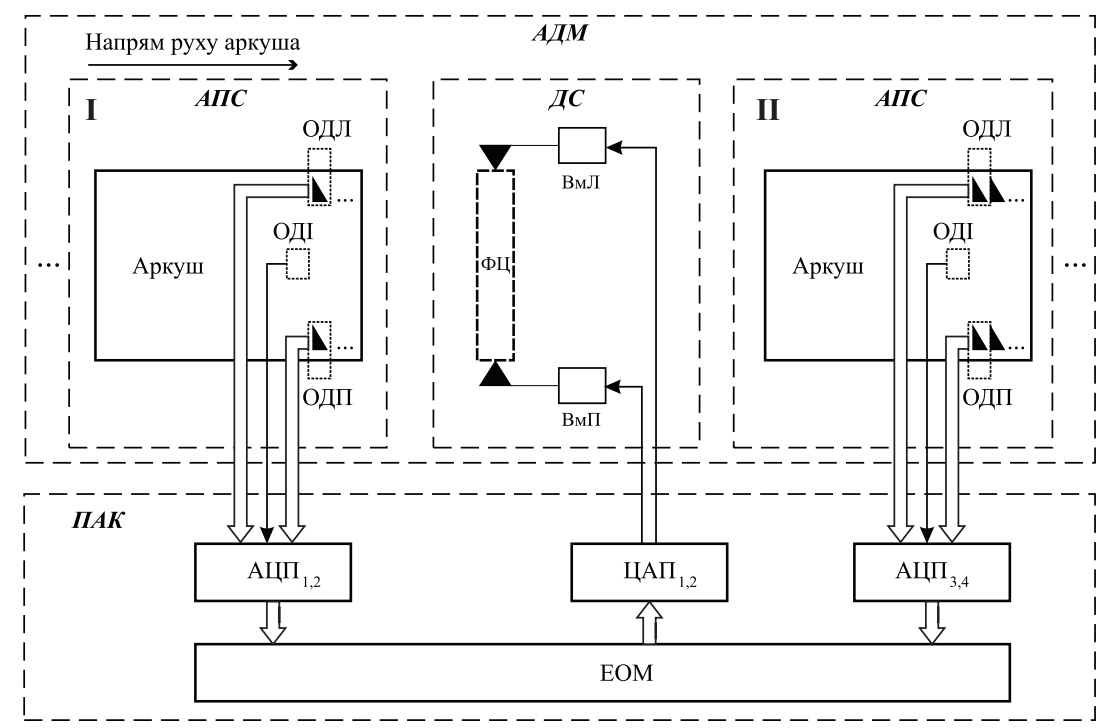

Рис. 1. Структурна схема цифрової системи інтегрального контролю суміщення фарб в аркушевих друкарських машинах: I, II - етапи інтегрального контролю суміщення фарб; АДМ - аркушева друкарська машина; АПС - аркушепередавальна система; ДС - друкарська секція; ОДЛ - оптичний датчик лівий; ОДП - оптичний датчик правий; ОДІ оптичний датчик ідентифікації аркуша; ФЦ - формний циліндр; ПАК програмно-апаратний комплекс; АЦП 1,2,3,4 - аналого-цифровий перетворювач; ЦАП 1,2 - цифро-аналоговий перетворювач 


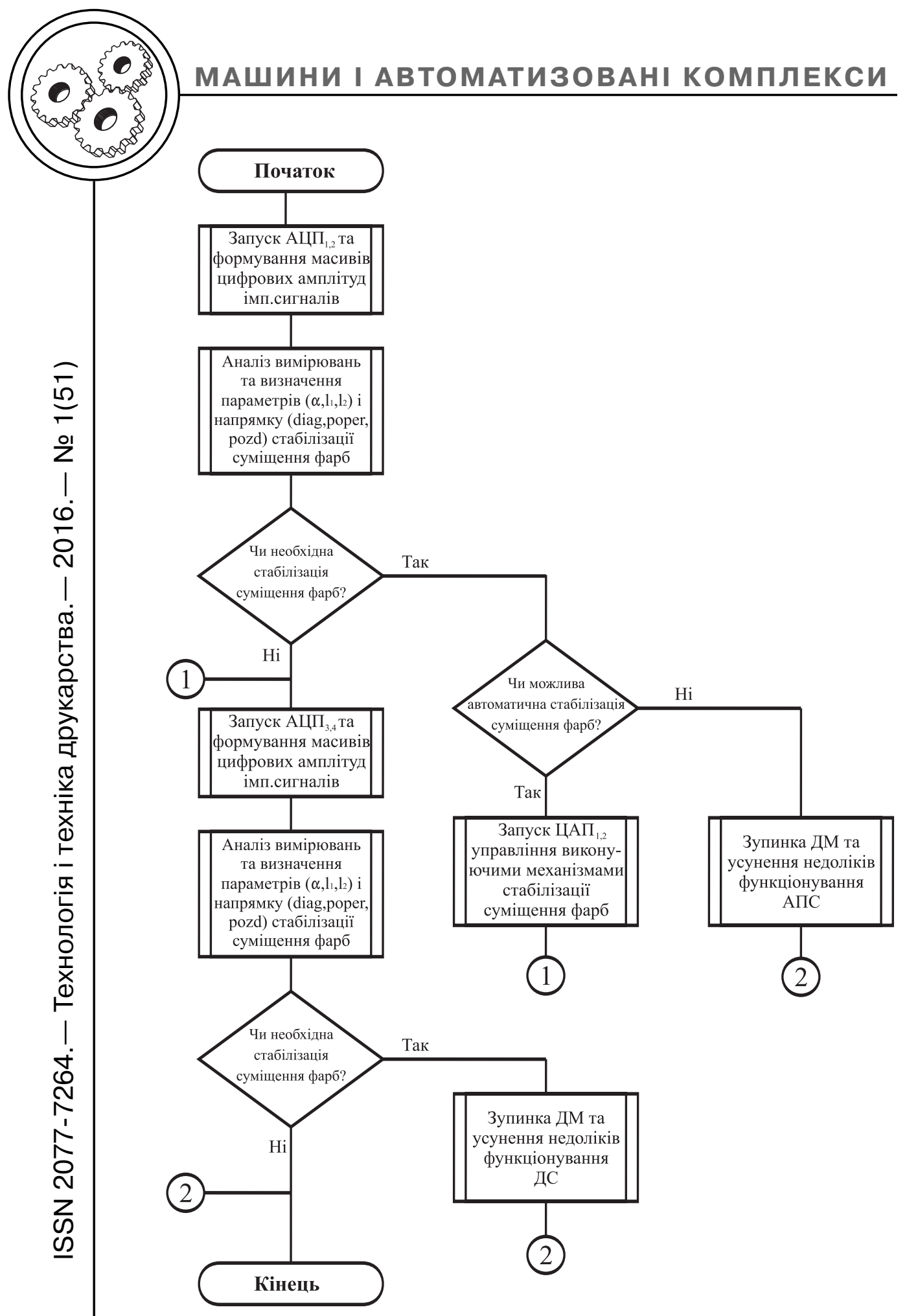

Рис. 2. Алгоритм функціонування цифрової системи інтегрального контролю суміщення фарб в аркушевих друкарських машинах

\section{6}


diag $\neq 0$, poper $\neq 0$, pozd $\neq 0$ ) та аналіз можливості реалізації стабілізації суміщення фарб в автоматичному режимі (умова проведення автоматичної стабілізації: $\alpha_{\min } \geq \alpha \geq \alpha_{\max }, \mathrm{I}_{1 \text { min }} \geq$ $\geq \mathrm{I}_{1} \geq \mathrm{I}_{1 \text { _max }}, \mathrm{I}_{2 \text { _min }} \geq \mathrm{I}_{2} \geq \mathrm{I}_{2 \text { _max }}$, де $\alpha_{\min }, \alpha_{\max }-$ мінімальний та максимальний кути діагонального зміщення формного

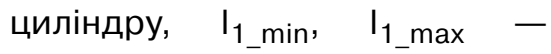
мінімальна та максимальна відстані колового зміщення формного циліндру; l 2 min, l 2_max $_{\text {max }}$ - мінімальна та максимальна відстані осьового зміщення формного циліндру), що залежить від характеристик функціонування виконавчих механізмів. Процес стабілізації суміщення фарб в друкарській секції здійснюється за допомогою цифро-аналогових перетворювачів (ЦАП 1,2 ), які подають керуючу напругу для управління кроковими двигунами керування лівою та правою опорами формного циліндра [5].

Другий етап інтегрального контролю суміщення фарб полягає у визначенні параметрів суміщення фарб $\left(\alpha, \mathrm{I}_{1}, \mathrm{I}_{2}\right)$ і напрямків їх стабілізації (diag, poper, pozd) на основі формування імпульсних сигналів 3 оптичних датчиків, які встановлюються у аркушепередавальній системі друкарської машини після друкарських секцій по обидві сторони проходження паперу й передають інформацію про суміщення фарб після нанесення друкарського відбитку за допомогою спеціальних міток, що друкуються на кожній друкарській секції.

Процес інтегрального контролю суміщення фарб в аркушевих друкарських машинах дозволяє локалізувати причини зміщення друкарських відбитків на задрукованому матеріалі внаслідок порушення функціонування аркушепередавальної системи або друкарських секцій.

\section{Висновки}

1. Цифрова система інтегрального контролю суміщення фарб на основі сучасних програмно-апаратних засобів та об'єктивних методів обробки і аналізу інформації забезпечує достовірність визначення параметрів суміщення фарб в аркушевих друкарських машинах, що дозволяє виконувати стабілізацію суміщення фарб $з$ визначеною точністю у реальному масштабі часу.

2. Застосування цифрової системи інтегрального контролю суміщення фарб дозволяє мінімізувати час локалізації порушення функціонування аркушевої друкарської машини, що забезпечує зменшення технологічних втрат процесу друку та підвищення якості друкованої продукції.

\section{Список використаної літератури}

1. Карпенко І. С. Дослідження моделей процесів стабілізації параметрів суміщення фарб у аркушепередавальних системах / І. С. Карпенко, В. Ф. Морфлюк // Технологія і техніка друкарства : зб. наук. праць - Київ : ВПІ НТУУ «КПІ», 2014. - № 1. - С. 30-36.

2. Штоляков В. И. Печатное оборудование : Учебник / В. И. Штоляков, В. Н. Румянцев. - М. : Изд-во МГУП, 2011. - 519 с. 


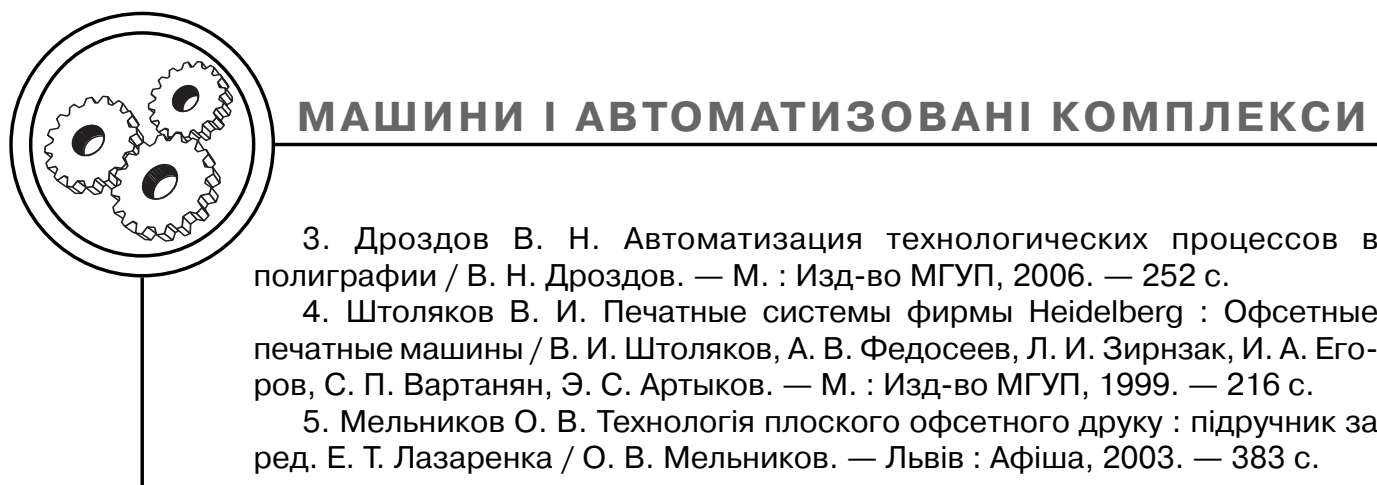

References

1. Karpenko, I. S., \& Morfliuk, V. F. (2014). Doslidzhennya modelei protsesiv stabilizatsiyi parametriv sumishchennya farb u arkusheperedaval'nykh systemakh [Research models of the processes stabilization the parameters of process register the colors in sheet transfer system]. Tekhnolohiia i tekhnika drukarstva - Technology and Technique of Typography, 1, 30-36. Retrieved from http://ttdruk.vpi.kpi.ua/article/view/31422 [in Ukrainian].

2. Shtolyakov, V. I., \& Rumyantsev, V. N. (2011). Pechatnoe oborudovanie [Printing equipment]. Moscow: Moskovskiy gosudarstvennyy universitet pechati [in Russian].

3. Drozdov, V. N. (2006). Avtomatizatsiya tekhnologicheskikh protsessov v poligrafii [Automation of technological processes in the printing]. Moscow: Moskovskiy gosudarstvennyy universitet pechati [in Russian].

4. Shtoljakov, V. I., \& Fedoseev, A. V., \& Zirnzak, L. I., \& Egorov, I. A., \& Vartanjan, S. P., \& Artykov, Je. S. (1999). Pechatnye sistemy firmy Heidelberg: Ofsetnye pechatnye mashiny [Heidelberg Printing Firm: Offset printing machines]. Moscow: Moskovskiy gosudarstvennyy universitet pechati [in Russian].

5. Mel'nykov, O.V. (2003). Tekhnolohiya ploskoho ofsetnoho druku [Technology offset lithography]. Lviv: Afisha [in Ukrainian].

В статье предложена цифровая система интегрального контроля совмещения красок для определения локализации нарушения функционирования листовой печатной машины, которая позволяет уменьшить технологические потери процесса печати и выполнять стабилизацию совмещения красок с определенной точностью в реальном масштабе времени.

Ключевые слова: совмещение красок; цифровая система интегрального контроля; продольное совмещение красок; поперечное совмещение красок; диагональное совмещение красок; стабилизация совмещения красок.

In the article proposes a digital integral control system of registration the colors to determine the localization of dysfunctions of sheet-fed printing press, which can reduce the loss of technological process and perform stabilization of registration $t$ he colors with certain accuracy in real-time.

Keywords: register the colors; digital integral control system; longitudinal register the colors; transverse register the colors; diagonal register the colors; stabilization of register the colors. 